\title{
Application of Earth Observation Technology to Site Selection and Development of Ecotourism Management Plans in Rural Ghana
}

\author{
Selase Kofi Adanu, ${ }^{1}$ Foster Kwami Mensah, ${ }^{1}$ Sesime Kofi Adanu, ${ }^{2}$ \\ Dziwornu Kwami Adanu, ${ }^{3}$ and Kabila Abass ${ }^{4}$ \\ ${ }^{1}$ Centre for Remote Sensing and Geographic Information Services, University of Ghana, PMB L17, Legon, Accra, Ghana \\ ${ }^{2}$ Institutional Research, Cheyney University of Pennsylvania, 31 Delvin Terrace, Wilmington, DE 19805, USA \\ ${ }^{3}$ Department of Economics and Finance, Ghana Institute of Management and Public Administration, \\ P.O. Box AH 50, Achimota, Accra, Ghana \\ ${ }^{4}$ Department of Geography and Rural Development, Kwame Nkrumah University of Science and Technology, Kumasi, Ghana \\ Correspondence should be addressed to Selase Kofi Adanu; sadanu@hotmail.com
}

Received 18 October 2012; Accepted 1 November 2012

Academic Editors: N. Frascaria-Lacoste, J. F. Negron, and P. Newton

Copyright (C 2013 Selase Kofi Adanu et al. This is an open access article distributed under the Creative Commons Attribution License, which permits unrestricted use, distribution, and reproduction in any medium, provided the original work is properly cited.

Production of development plans is vital for sustainable ecotourism development given the increasing competition for land to satisfy various human needs including agriculture, timber, and wood energy. Such human activities cause rapid destruction of wildlife habitat and loss of indigenous tree species. To enhance sustainable use of the flora and fauna to promote rural tourism in Ghana, seven eco-tourism sites have been surveyed to produce data for management plans to be developed for these sites. The survey focused on the status of flora and fauna at the sites, infrastructure, cultural dynamics, cross-border issues, and revenue mobilization. Key findings indicate lack of infrastructure at the sites and substantial loss of forest cover over seventeen years covered by the survey.

\section{Background}

Ecotourism is becoming a leading world industry especially in developing countries so far as provision of employment opportunities is concerned $[1,2]$. Expansion in this sector has brought to the fore the role of ecotourism in poverty alleviation in developing countries [3-7]. Even though ecotourism is expanding, lack of adequate planning and management of sites poses a challenge to sustainable ecotourism. For example, failure to plan and introduce encroachment buffers in tourism development around the Bohorok river in Indonesia resulted in encroachment of the ecotourist sites by housing development [8].

Nature based tourism involves the enjoyment of wildlife and plants at undeveloped natural areas [9]. Sustaining benefit flows is however heavily dependent on proper planning and management of tourism sites. This calls for the development and implementation of comprehensive plans. Such plans must provide management with detailed sitespecific guidelines to tourism development and respond to pressure on tourism infrastructure and the environment [10]. In addition to the existence of pristine forests and diverse wildlife, some sites in Ghana are also characterized by the presence of cultural resources like missionary buildings, slave markets, and caves. Development plans in Ghana therefore require an integrated approach that accounts for such cultural resources and involve private-public sector partnerships, interagency coordination, and community involvement.

Unfortunately, the history of tourism management in Ghana reveals the absence of any comprehensive tourism development plan. Tourism resource management in Ghana has followed a very unsystematic approach that involves occasional short-term studies and implementation of programs that are incoherent and ineffective in addressing 
problems in the sector. Some past studies and programs on the tourism sector in Ghana include an evaluation of the country's tourism resources in 1970 aimed at cataloguing and classifying the country's potential tourism resources [11]. Subsequent studies focused on tourism impact assessments [12] and tourism multiplier effects [13]. Tourism impact assessments are necessary for purposes of creating environmental strategies for tourism development to minimize environmental costs associated with human impact on the natural environment [14]. Tourism multiplier effects on the other hand focus on the job creation potentials of tourism and the general welfare improving effects of tourism on indigenous communities. Although both employment in the tourism sector and tourist arrivals in Ghana have been on the rise since 2005 [15] the sector could benefit from increased growth if research findings on the sector's performance are properly utilized to address managerial problems and promote efficient use of tourism resources. Apart from the management problems, the tourism industry in Ghana is beset with problems such as expensive hotels, cheating of tourists by untrained taxi drivers, poor road infrastructure, and lack of adequate books and brochures for tourists in Ghana. Further, tourism sites in Ghana face increasing pressures from agricultural expansion, logging, and wood energy exploitation due to high population growth.

Tourism resource management in Ghana was decentralized along with the general decentralization of governance which began with the introduction of the Local Government Law (PNDC Law 207) in 1988/89 [16]. This policy direction is the trend in tourism resources management in many other developing countries $[17,18]$. Decentralization of tourism management in Ghana provided opportunities for district and municipal assemblies to directly participate in the management of tourism resources in their localities. Participation of local authorities normally includes collecting access fees at sites and regulating the use of site resources. Roping-in all stakeholders in the management of tourism resources clearly provides incentives to all stakeholders to contribute effectively to the efficient management of tourism in Ghana. On the other hand, handing over tourism management to inexperienced and untrained local leaders without management plans is likely to result in further decline in tourism sector outcomes.

This paper assesses the state of ecotourism resources at seven selected ecotourism sites and presents results of a survey that highlights challenges and opportunities to tourism management at the selected sites. The paper identifies the relevant factors that affect sustainable development of tourism at these sites and provides data for the production of management plans to address the identified problems.

\section{Methodology}

The research team worked in conjunction with officials of the district and municipal assemblies to identify the seven sites surveyed in this paper. The selected tourism sites are LikpeTodome, Logba-Tota, and Tafi-Atome in the Volta Region. The other sites include Boabeng-Fiema and Kunsu cultural
TABLE 1: Distribution of respondents across the seven sites.

\begin{tabular}{lc}
\hline Towns/Villages & Number of respondents \\
\hline Boabeng Fiema & 36 \\
Logba Tota & 33 \\
Likpe Todome & 34 \\
Kayoro & 34 \\
Kunsu & 35 \\
Akyeremanteng & 34 \\
Tafi Atome & 34 \\
\hline Total & 240 \\
\hline
\end{tabular}

sites in the Brong-Ahafo Region. The remaining sites are Akyeremanteng in the Eastern Region and Kayoro in the Upper East Region. All sites were visited to identify and describe the physical attributes of the sites. The focal attributes examined at each location are tree and animal species, water bodies, cultural sites, and infrastructural adequacy. Figure 1 below shows the location of the seven sites and the regions within which they are located.

Next, stakeholder interviews were conducted to interview five local tourism management committee members in Boabeng Fiema, Logba Tota, and Likpe Todome. At Kayoro, Kunsu and Akyeremanteng no such committees exist. As a result, the local chiefs of Kayoro and Kunsu and the assembly member for Akyeremanteng were interviewed.

Questionnaires were also administered to households in the study settlements to collect biodata, and information on demography, flora and fauna, and water resources. Other questions included on the household questionnaires covered site facilities, site marketing and management, contribution of tourism to local infrastructural development, and negative effects of tourism on the culture and lives of the people. A total of 240 households in the seven towns/villages responded to the questionnaires. In exceptional cases where household heads were not available to respond to questions, youth aged between 16 and 22 years that have adequate knowledge on issues contained in the questionnaire were interviewed. Table 1 shows the distribution of respondents to the household survey.

Finally, satellite image analysis was performed to determine flora changes across the various sites. Flora changes have important implications for fauna and biodiversity since it serves as habitat for wildlife. The satellite data used for the analysis is made up of Landsat TM 1990, Landsat ETM+ 2000 and Aster 2007 images. All the satellite images were dry season images and were classified for all seven sites to determine forest and woody vegetation cover changes between 1990 and 2007. Unsupervised classification method was done using ERDAS IMAGINE 2011 software.

\section{Study Location and Physical Environment}

The location and physical environment of the seven sites visited are provided as follows (Table 2). Akyeremanteng is located in the Akuapem North District of the Eastern Region and falls on latitude $06^{\circ} 19^{\prime}$ and longitude $0^{\circ} 21^{\prime}$. 


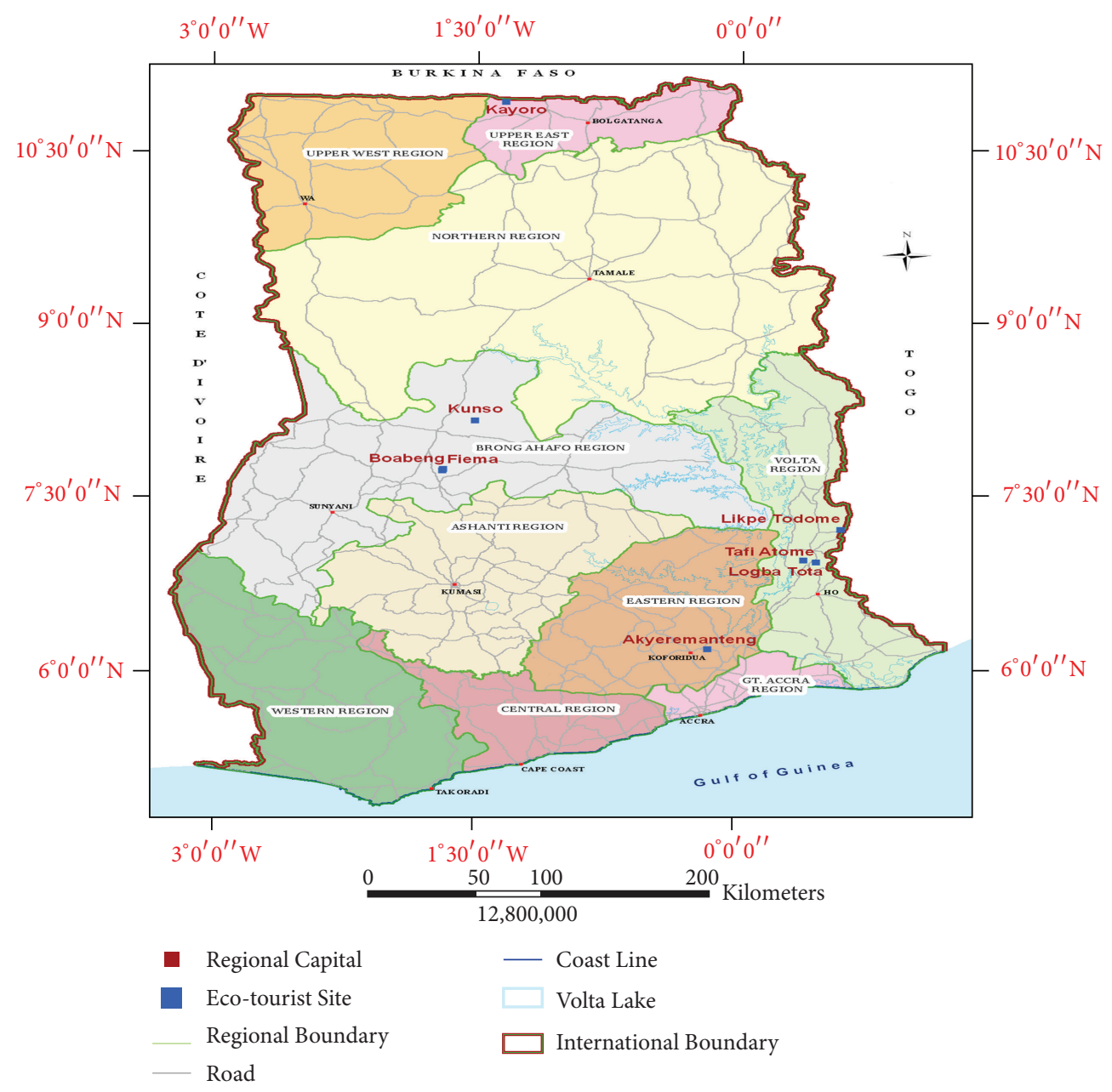

FIGURE 1: Map of Ghana showing selected sites.

TABLE 2: Location of study sites.

\begin{tabular}{lcccc}
\hline Site name & District & Region & Latitude & Longitude \\
\hline Akyeremanteng & Akuapem North & Eastern Region & $06^{\circ} 19^{\prime}$ & $0^{\circ} 21^{\prime}$. \\
Kunsu & Kintampo North & Brong Ahafo & $8^{\circ} 45^{\prime} \mathrm{N}-7^{\circ} 45^{\prime} \mathrm{N}$ & $1^{\circ} 20^{\prime} \mathrm{W}-2^{\circ} 1^{\prime} \mathrm{E}$ \\
Logba Tota & Hohoe Municipal & Volta & $6^{\circ} 45^{\prime} \mathrm{N}-7^{\circ} 15^{\prime} \mathrm{N}$ & $0^{\circ} 15^{\prime} \mathrm{E}-0^{\circ} 45^{\prime} \mathrm{E}$ \\
Tafi Atome & Hohoe Municipal & Volta & $6^{\circ} 45^{\prime} \mathrm{N}-7^{\circ} 15^{\prime} \mathrm{N}$ & $0^{\circ} 15^{\prime} \mathrm{E}-0^{\circ} 45^{\prime} \mathrm{E}$ \\
Likpe Todome & Hohoe Municipal & Volta & $6^{\circ} 45^{\prime} \mathrm{N}-7^{\circ} 15^{\prime} \mathrm{N}$ & $0^{\circ} 15^{\prime} \mathrm{E}-0^{\circ} 45^{\prime} \mathrm{E}$ \\
Boabeng Fiema & Nkoranza & Brong Ahafo & $7^{\circ} 35^{\prime} \mathrm{N}-7^{\circ} 55^{\prime} \mathrm{N}$ & $1^{\circ} 15^{\prime}-1^{\circ} 55^{\prime} \mathrm{W}$ \\
Kayoro & Kassena Nankana & Upper East & $11^{\circ} 10^{\prime} \mathrm{N}-10^{\circ} 3^{\prime} \mathrm{N}$ & $10^{\circ} 1^{\prime} \mathrm{W}$ \\
\hline
\end{tabular}

Kunsu is located in the Kintampo North Municipality of Brong-Ahafo region between latitudes $8^{\circ} 45^{\prime} \mathrm{N}$ and $7^{\circ} 45^{\prime} \mathrm{N}$, and longitude $1^{\circ} 20^{\prime} \mathrm{W}$ and $2^{\circ} 1^{\prime} \mathrm{E}$. Logba-Tota, Tafi-Atome, and Likpe-Todome all under the Hohoe Municipality of the Volta Region lie within latitudes $6^{\circ} 45^{\prime} \mathrm{N}$ and $7^{\circ} 15^{\prime} \mathrm{N}$ and longitude $0^{\circ} 15^{\prime} \mathrm{E}$ and $0^{\circ} 45^{\prime} \mathrm{E}$. Boabeng-Fiema in the Nkoranza District is located on latitude $7^{\circ} 35^{\prime} \mathrm{N}$ and $7^{\circ} 55^{\prime} \mathrm{N}$ and longitudes $1^{\circ} 15$ and $1^{\circ} 55^{\prime} \mathrm{W}$, and, finally, the Kayoro site is located in the Kassena Nankana district approximately between latitudes $11^{\circ} 10^{\prime} \mathrm{N}$ and $10^{\circ} 3^{\prime} \mathrm{N}$ and longitude $10^{\circ} 1^{\prime} \mathrm{W}$. Further, the selected sites are located mostly in mountainous areas ranging in elevation from 60 meters to 460 meters above sea level. Akyeremanteng for instance stands at heights ranging between 381 meters and 488 meters above sea level while Boabeng-Fiema lies at heights falling between 153-305 meters. The heights of the other sites are Logba-Tota, 60-150 meters, and Likpe-Todome, 460 meters (average). Several of these sites are part of the famous Akuapim Togo Ranges that are characterized by valleys that are a delight to watch. Rivers and tree species of different kinds also exist in the forests and closed woodlands. 
1990

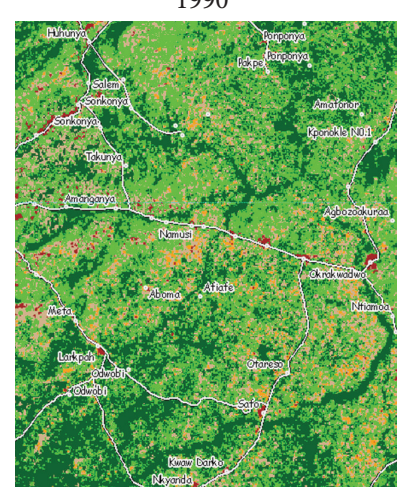

2000

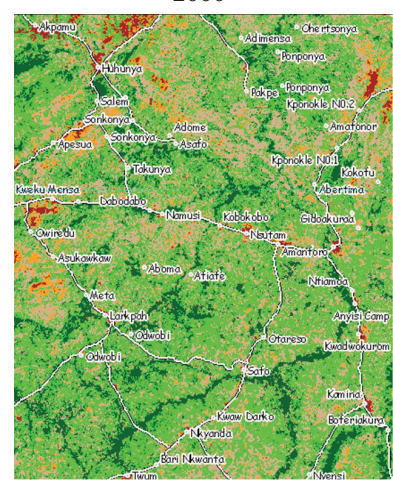

2007

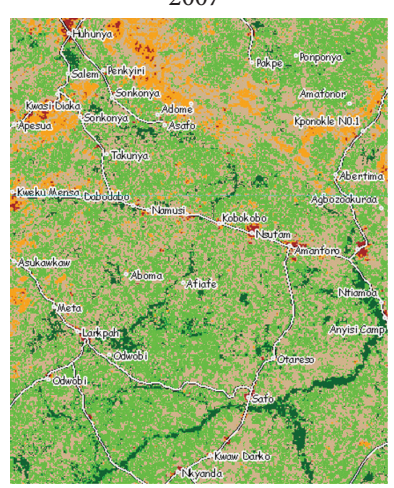

Multiple canopy (rain-forest with three layers of multiple species obstructing sunlight from reaching the floor)

$\square$ Single canopy (no-shade, secondary regrowth, other trees with no overhead canopy) crop farm with mixture of crops fallow regrowth

$\square$ Shrubs, herbaceous/grass cover and fallow vegetation which dry up in the dry season exposing partly the soil cover, freshly cleared/planted areas of fallow and access road

$\square$ Grass/herbaceous cover

Bare soils and built up surfaces of settlements

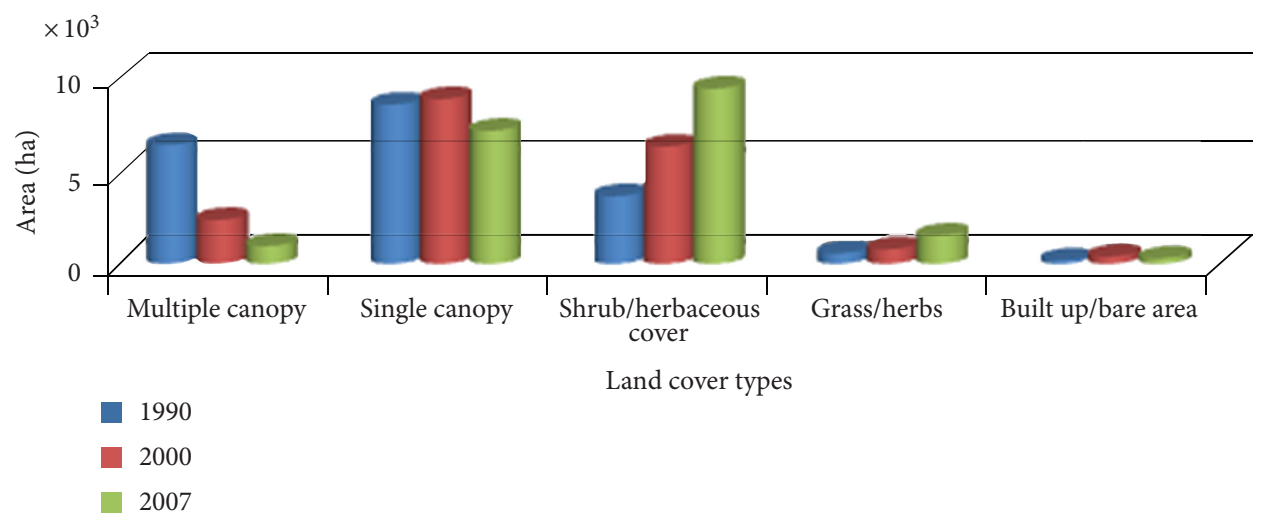

(b)

Figure 2: (a) Time series classified satellite imagery for Akyeremanteng (1990-2007). (b) Land cover changes in Akyeremanteng (1990-2007).

\section{Results}

Results of the survey analysis are presented below. The results focus on the main attractions in each of the seven sites and particularly discuss the state of flora and fauna, infrastructural facilities, site encroachment, and boundary issues, and the state and potential uses of cultural resources close to the major tourism sites. The satellite image analysis of flora at the sites classified vegetative cover into four main groups. These are multiple canopy forests, single canopy forests, shrub/herbaceous vegetation, grass/herbs, and builtup/bare areas. The presentation of site-specific results follows. In Northern Ghana (Kayoro) where the vegetation is typically savanna the flora has been categorized as close savanna woodland, dense shrub with open savanna, herb/grass, grassland and built-up/bare area.
4.1. Akyeremanteng. The dominant attraction at Akyeremanteng is the Akaa waterfall. The Akaa waterfall is among the most attractive waterfalls in Ghana, but remains one of the lesser known falls. This is most likely due to poor marketing and management of the site. The flora of the site is characterized mostly by closed and open forest canopy vegetation interspersed with shrubs and grasslands. The predominant forest trees are Wawa (Triplochiton scleroxyon), Mahogany (Khaya ivorensis), and Odum (Milicia excelsa). Other tree species are Ofram, Kane, Senya, and Nyina. The fauna around the waterfall comprise varieties of animals such as antelopes, monkeys, wild goats, rabbits, zebras, elephants, and squirrels to mention a few. Birds such as doves, eagles, parrots, hawks, guinea fowls, owls, ducks, bats are also found at the sites. The satellite image analysis of vegetation cover at the site is shown in Figures 2(a) and 2(b) for 1990, 2000, and 2007. 
The figures indicate that in 17 years, the size of the multiple canopy forests experienced significant reduction from 6,498 hectares to 975 hectares while single canopy forests decreased from 8,693 hectares to 7,271 hectares. In contrast, shrub/herbaceous vegetation cover increased from 3,699 hectares in 1990 to 9,576 hectares in 2007 while grass/herbs increased from 576 hectares in 1990 to 1,543 hectares in 2007.

The multiple and single canopy forests have thus declined by 85 percent and 16 percent, respectively, over the 17 year period. On the other hand shrub/herbaceous vegetation covering increased by 159 percent over the same period. The drastic decline in multiple and single canopy forests poses a serious threat not only to the fauna at the site but also the continued existence of the waterfall as loss of forest cover mean loss of animal habitat and exposure of the waterfall to direct sun shine. Direct exposure of the waterfall to sunlight increases evapotranspiration and silting of water ways thus reducing water flow.

The road to Akaa waterfall is also in bad shape. Difficult transportation to the site is enough to deter tourists from visiting the waterfall. Further, theAkaa waterfall site lacks a welcome center where tourists can take rest and receive guidance that will enrich their experience at the site.

4.2. Kunsu Cultural Site. The main attractions at the Kunsu site are a slave market and some very remarkable caves. Although there is a welcome center at Kunso, the area lacks hotel accommodation for visiting tourists. The lack of hotel accommodation places a major constraint on growth of the tourism industry in the area. It is however evident that investment in hotel facilities especially by the private sector is heavily dependent on the size of the tourist market in the area. It is therefore important for the local leaders to initialize the growth process by properly planning the sector and reinvesting funds obtained from tourist visits.

Kunsu is a relatively forested area and the presence of heavy vegetative covering creates a cool tropical climate environment at this site. The forest structure in the area is however experiencing dramatic changes. Analysis of satellite image of the area indicates that the multiple canopy forests have declined from 17,474 hectares in 1990 to 3,982 hectares in 2007. This represents a 77 percent decrease in multiple canopy forests and averages to a loss of about 794 hectares per annum. The single canopy forest cover however increased marginally from 10,786 hectares to 11,651 hectares in 2007 representing 8 percent increase in single canopy forests. Shrub/herbaceous cover around the site in 1990 was 9,822 hectares and 19,937 hectares in 2007.

Grass/herb cover also increased from 764 hectares in 1990 to 2,497 hectares in 2007 . The satellite image analysis therefore shows that shrub/herbaceous and grass/herb coverings went up by 103 percent and 227 percent, respectively, over the 17 year period to make up for the large decline in the multiple canopy forests.

The analysis of vegetative cover at Kunsu reveals an early stage of drastic deterioration of forest cover. Multiple canopy forest covers are quickly converting into single canopy while the single canopy forest coverings convert into Shrub/herbaceous coverings. Note the dramatic rise in the single canopy forests from 10,786 hectares in 1990 to 16,824 hectares in 2000 before declining sharply to 11,651 hectares by 2007 (Figure 3).

4.3. Tafi-Atome, Logba-Tota, and Likpe-Todome. Logba-Tota, Tafi-Atome, and Likpe-Todome form a part of the well known Akwapim-Togo ranges. At Tafi-Atome, the Mona monkey sanctuary is the main attraction. Here, the endangered Mona monkeys are treated as sacred animals, protected from harm and allowed to move freely throughout the settlement. In Likpe-Todome and Logba-Tota, the Wanjakli and Akpom waterfalls, respectively, serve as the main attractions in addition to cave sites. All three villages have welcome centers. The centers are however highly underutilized since they lack electricity, running water, and water closet toilet facilities.

Residents at the Likpe-Todome site which is close to the republic of Togo border complained of cross-border annual bushfire occurrences in the surrounding forests attributed to the Togolese residents. Again, a major threat to tourism in the area is the high rate of deforestation observed in the area. See Figure 4(c) for graphical illustration.

Direct tourist contribution to economic development in the localities is substantial. For example, a tourist provided pipe-borne water for the people of Likpe Todome so they are able to enjoy clean drinking water and mitigate water borne diseases in the community. Also, at Logba Tota, a clinic and school buildings were financed by individual tourists who visited the site. At Tafi Atome, Peace Corps volunteers from the United States of America have constructed a shelter for volunteers working at the site.

Within this region in the Hohoe municipality multiple canopy forest cover declined from 51,659 hectares in 1990 to 10,354 hectares in 2007 while single canopy forests declined from 53,777 hectares in 1990 to 51,289 hectares by 2007 . The shrub/herbaceous cover increased from 39,306 hectares in 1990 to 79,762 hectares in 2007 while the grass/herb cover increased from 8,333 hectares in 1990 to 12,665 hectares in 2007.

4.4. Boabeng-Fiema. At Boabeng-Fiema in the Nkoranza North district, the black and white monkeys sanctuaries as well as the mona monkeys represent the main attractions. Visitors to Boabeng-Fiema can take memorable forest walks along well-shaded trails marked by beautiful indigenous flowers and trees and sightings of many birds and butterflies.

The vegetative cover in this region is however also under severe pressure from human activities. The multiple canopy forest cover at Boabeng Fiema decreased from 11,380 hectares in 1990 to 3,236 hectares in 2007.

The single canopy vegetation cover on the other hand increased from 4,744 hectares in 1990 to 5,224 hectares in 2007. As far as the shrub/herbaceous cover is concerned, an increase from 2,502 hectares in 1990 to 7,722 hectares in 2007 was observed (Figure 5). 
1990

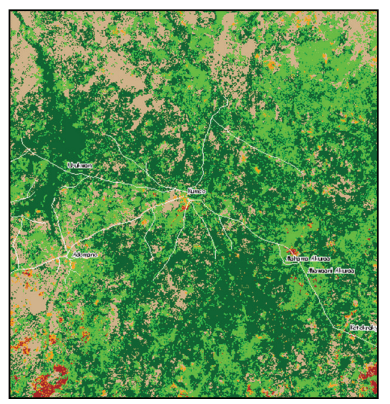

2000

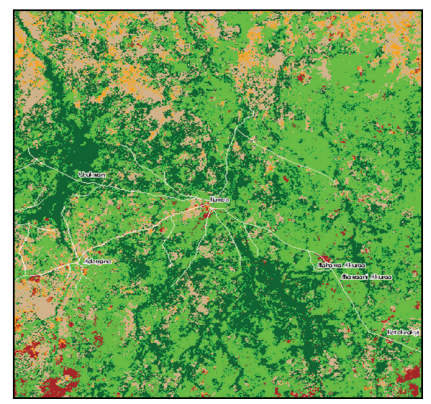

2007

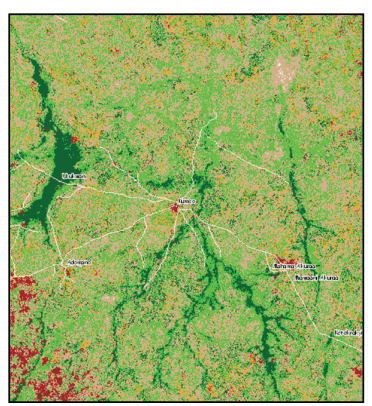

Multiple canopy (rain-forest with three layers of multiple species obstructing sunlight from reaching the floor)

$\square$ Single canopy (no-shade, secondary regrowth, other trees with no overhead canopy) crop farm with mixture of crops fallow regrowth

$\square$ Shrubs, herbaceous/grass cover and fallow vegetation which dry up in the dry season exposing partly the soil cover, freshly cleared/planted areas of fallow and access road

$\square$ Grass/herbaceous cover

Bare soils and built up surfaces of settlements

(a)

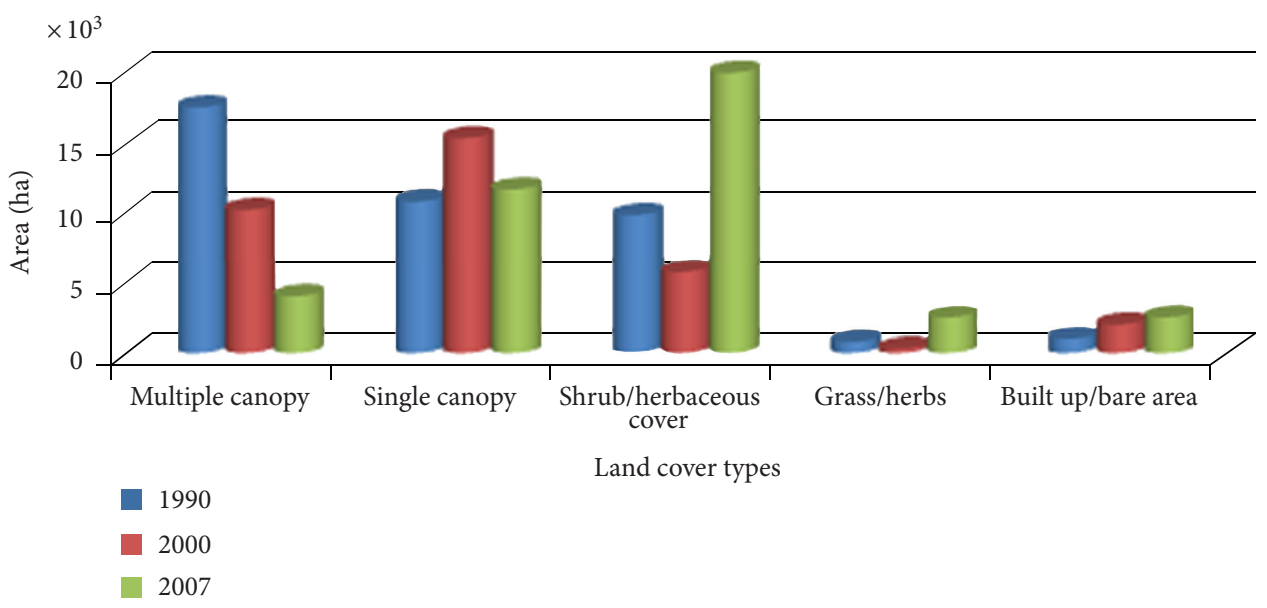

(b)

Figure 3: (a) Time series classified satellite imagery for Kunsu (1990-2007). (b) Land cover changes in Kunsu in 1990, 2000 , and 2007.

4.5. Kayoro. The main tourist attraction in Kayoro is wildlife. Wildlife in the area includes elephants, wild cows, birds, and antelopes. The vegetative cover at Kayoro is more of savanna woodland type vegetation which is in contrast with the relatively forested vegetative covers analyzed at previously discussed sites. The close savanna woodland cover provides an excellent habitat for the wildlife population in the area. Unfortunately, the vegetative cover here is also under stress due to increasing population in the area. In fact, the size of the closed savannah woodland declined from 23,622 hectares in 1990 to 14,702 hectares by 2007. Similarly, the dense shrub land with open savanna woodland vegetation decreased from 149,956 hectares to 87,260 hectares from 1990 to 2007. Herbaceous/grass cover on the other hand increased from 131,777 hectares in 1990 to 169,723 hectares in 2007 while grassland increased from 43,071 hectares in 1990 to 64,545 hectares in 2007 (Figure 6).
The location of Kayoro ecotourist site close to the Burkina-Faso border brings to the fore cross-border and human-wildlife conflicts. Ghanaians at Kayoro who live close to the Burkina-Faso border, a wildlife corridor for elephants, wild cows, birds, antelopes, and other animals, claim that bushfire problems that affect the habitat of animals can be attributed to the people of Burkina-Faso. There is also the issue of humans encroaching on wildlife habitats largely attributed to human population growth. Consequently, the natural habitat occupied by wildlife is experiencing rapid encroachment through food crop production and human settlement.

Another issue of considerable importance is the loss of crops and livestock caused by destructive elephants and wolves, respectively. Often, residents' response to these destructive activities of the wildlife is to poach the already endangered animals responsible for the destruction thus 


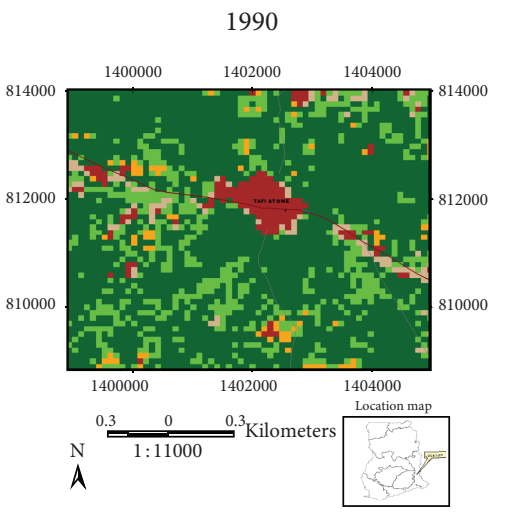

Close canopy vegetation with more trees

$\square$ Open canopy/dense shrubland with scattered trees

Shrubs, herbaceous/grass cover

$\square$ Grass/herbaceous cover

1990

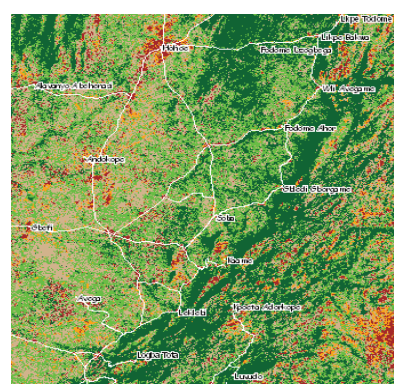

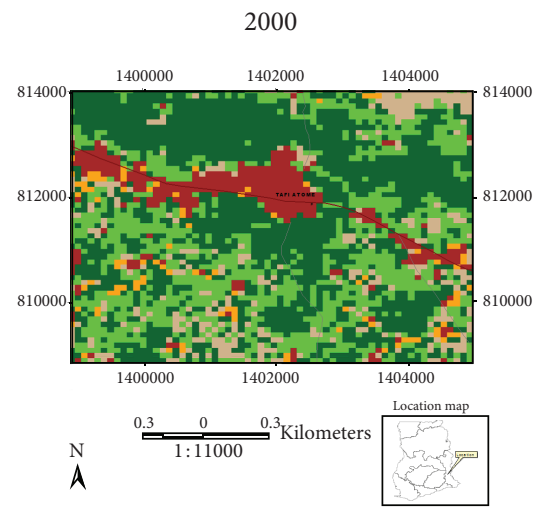

Bare soils and built up surfaces of settlements

\# Town/village

N Road

$\sim$ Footpath/track

(a)

2000

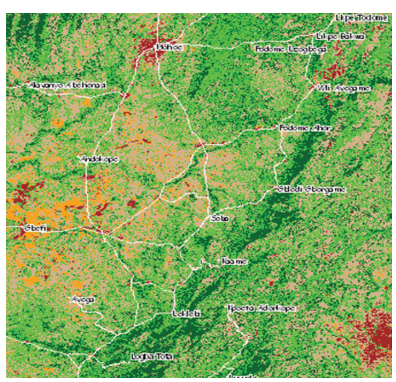

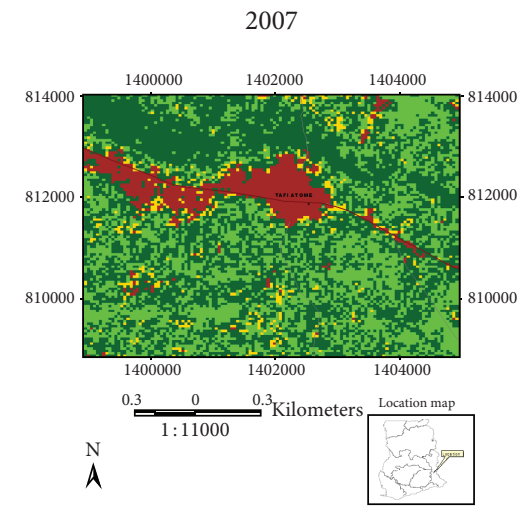

812000

Multiple canopy (rain-forest with three layers of multiple species

obstructing sunlight from reaching the floor)

Single canopy (no-shade, secondary regrowth, other trees

with no overhead canopy) crop farm with mixture of crops fallow regrowth

$\square$ Shrubs, herbaceous/grass cover and fallow vegetation which dry up in the dry season exposing partly the soil cover, freshly cleared/planted areas of fallow and access road

$\square$ Grass/herbaceous cover

Bare soils and built up surfaces of settlements

(b)

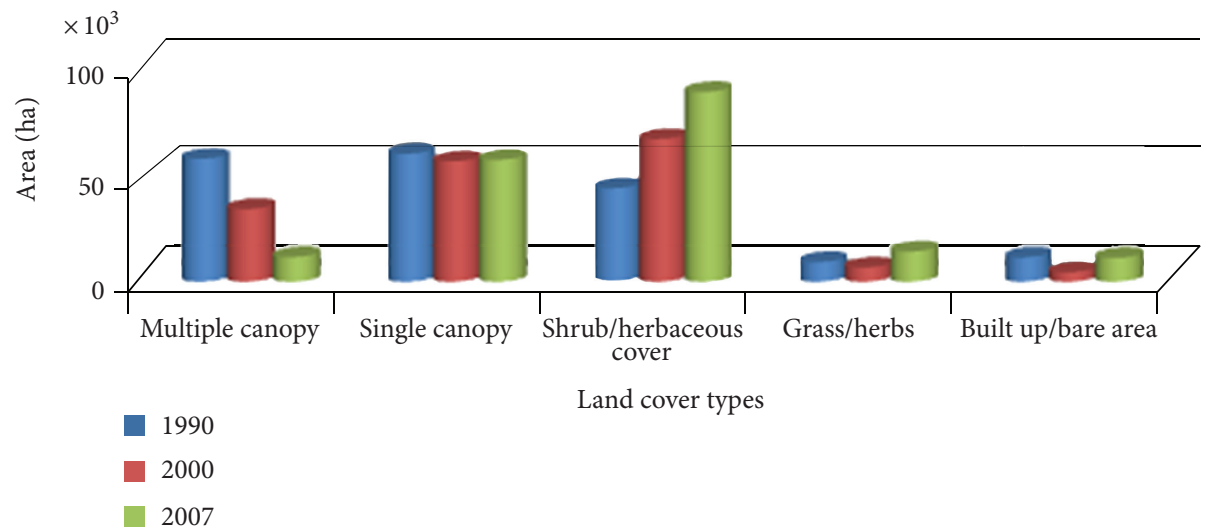

(c)

Figure 4: (a) Time series classified satellite imagery for Tafi Atome (1990-2007). (b) Time series classified satellite imagery for Logba Tota and Lipke Todome (1990-2007). (c) Land cover change in Logba Tota, Tafi Atome, and Likpe Todome in 1990, 2000 , and 2007. 
1990

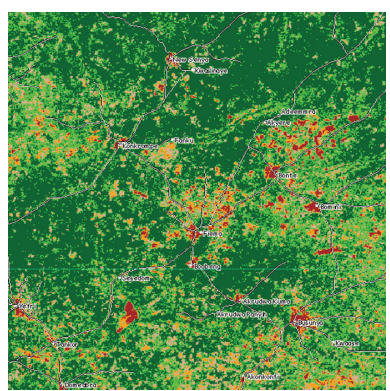

2000

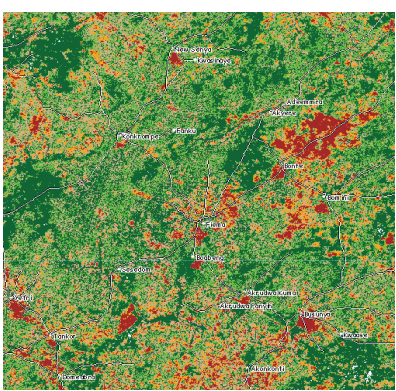

2007

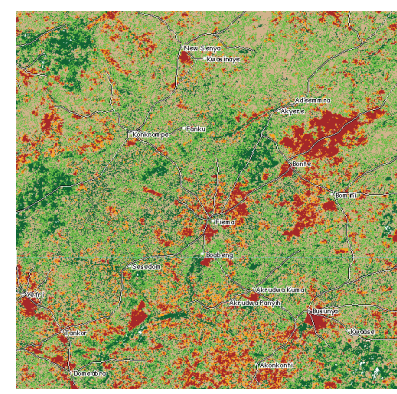

Multiple canopy (rain-forest with three layers of multiple species obstructing sunlight from reaching the floor)

$\square$ Single canopy (no-shade, secondary regrowth, other trees with no overhead canopy) crop farm with mixture of crops fallow regrowth

$\square$ Shrubs, herbaceous/grass cover and fallow vegetation which dry up in the dry season exposing partly the soil cover, freshly cleared/planted areas of fallow and access road

Grass/herbaceous cover

Bare soils and built up surfaces of settlements

(a)

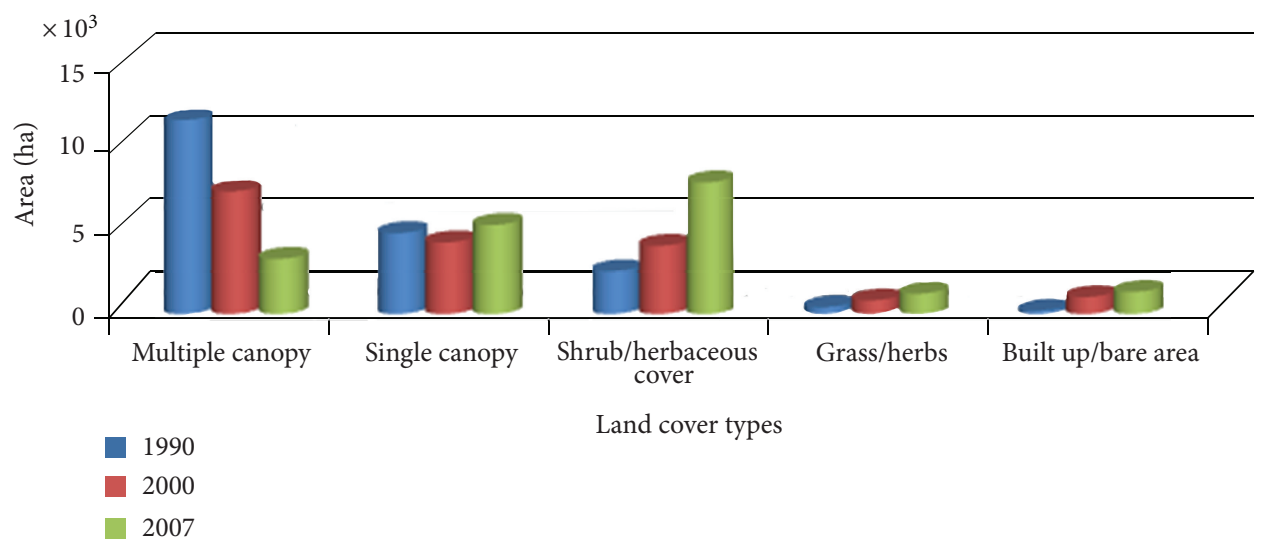

(b)

FIgURE 5: (a) Time series classified satellite imagery for Boabeng Fiema (1990-2007). (b) Land cover change in Boabeng-Fiema 1990, 2000, and 2007.

further depleting their population. Respondents in the Kayoro locality admit that the animals often drift towards the Burkina-Faso side of the border than the Ghana side because they feel safer at the Burkina-Faso side where rules against poaching are strictly enforced. Finally, Kayoro also lacks a visitor's welcome center.

\section{Discussion and Conclusions}

Evaluation of the seven ecotourism and cultural sites provides a very sound understanding of the physical environment and prospects for ecotourism development at the selected sites. Weaknesses identified at the study sites provide opportunity for developing management plans to address such weaknesses. For instance, the annual loss of forest cover observed between 1990 and 2007 gives a clear signal of declining habitat for wildlife due to deforestation and forest fragmentation. Fragmented forest landscapes are complex and heterogeneous systems that are influenced by factors such as size of the landscape, degree of forest remnant isolation, and habitat changes induced by forest edge effects [19]. These changes in forest landscapes often affect both the structure and function of forest ecosystems thereby causing stochastic fluctuation of reduced animal and plant populations [2022]. Habitat loss negatively affects species richness which is a salient attraction for tourists [23]. As a result, strategies for halting the decline must be clearly outlined in the management plans. The extensive data gathered from all the sites is adequate for evaluating the strengths and weaknesses of the sites, which forms the basis for developing very comprehensive management plans for all the seven sites identified.

Other challenges include the absence of welcome centers at Akyeremanteng and Kayoro. At Tafi-Atome, Logba-Tota, and Likpe-Todome there are welcome centers, but the centers lack electricity, running water, and water closet toilet facilities 

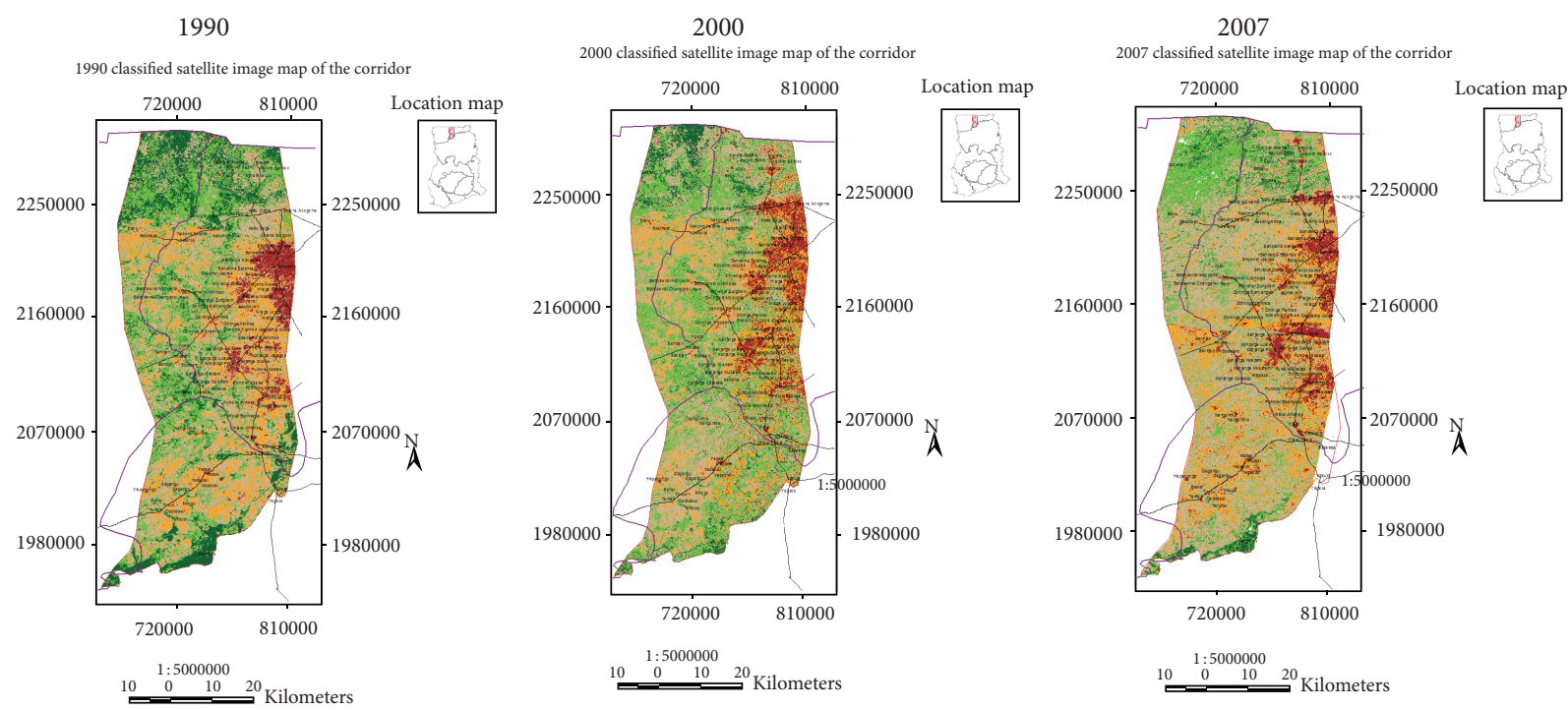

Close savanna woodland

$\square$ Dense shrubland with open savanna woodland

$\square$ Herbaceous/grass cover

$$
\begin{aligned}
& \text { \# Town/village } \\
& \sim \text { Road } \\
& \square \text { Regional Boundary }
\end{aligned}
$$

$\square$ Grassland/scattered herbaceous cover

Bare soils and built up

surfaces of settlements

(a)

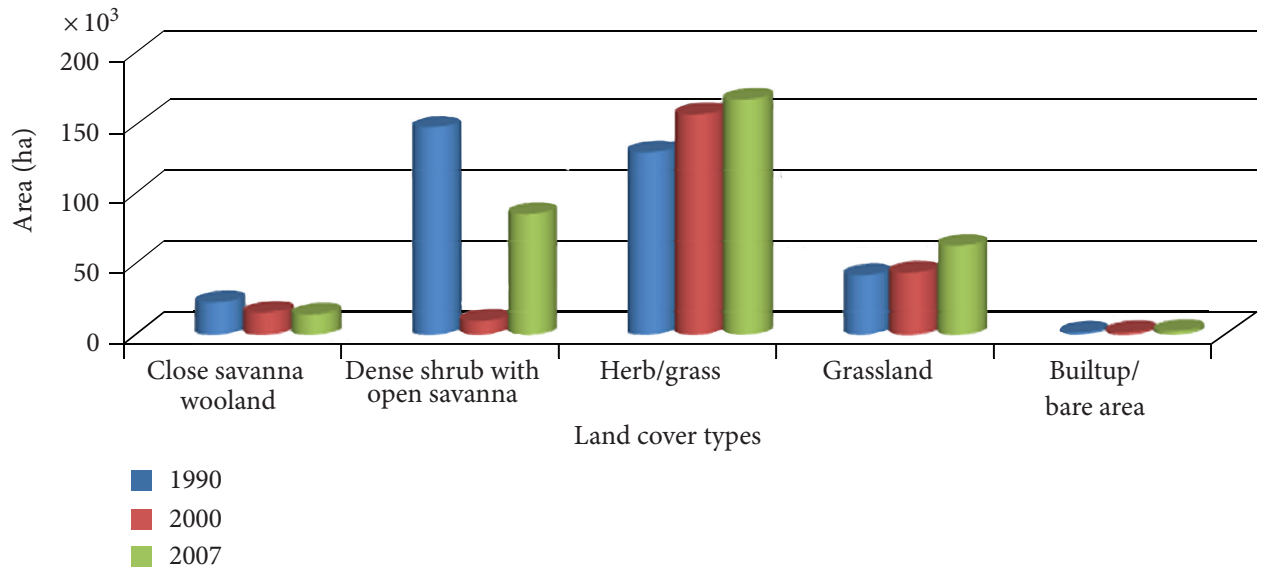

(b)

Figure 6: (a) Time series classified satellite imagery for Kayoro (1990-2007). (b) Land cover change in Kayoro in 1990, 2000 , and 2007.

for visitors. This represents a major drawback to developing the tourism industry in these areas. The lack of hotel/motel accommodation for visitors also poses a big challenge to tourism development. At Boabeng-Fiema and Tafi-Atome accommodation facilities have been provided at the welcome centers. However, during moments of large turnout of tourists, accommodation becomes a major constraint. At Kayoro, Kunsu, Akyeremanteng, and Logba-Tota no accommodation is available to tourists.
In addition to ecotourism, cultural tourism facilities such as old missionary buildings, slave markets, cave sites, festivals, and funerals have become interesting tourist attractions. At Kunsu and Likpe-Todome, for example, caves serve as cultural tourist attractions in addition to a slave market in Kunsu.

In general, poor infrastructure, expanding human settlement, and poaching represent the major threats to tourism in the selected sites. The study revealed that tourism 
advancement is being hampered by the bad nature of road infrastructure, which makes travelling uncomfortable. Bad road conditions in the form of untarred roads and bitumen surfaced roads with lots of pot holes make journeys to the tourist sites unpleasant. The untarred roads also get dusty in the dry season making travelling unbearable. Negative changes to the forest cover (decline of forest and woodland cover) can be explained by various factors such as logging, expansion of agricultural lands and bush burning. Other activities such as cutting of trees for wood energy production are additional drives to deforestation and decrease of the woody vegetation cover.

As far as opportunities are concerned, the sites were found to be inhabited by diverse tropical forests, animal and bird varieties, butterflies, and water bodies. Unfortunately, parts of the flora and fauna have not been extensively researched to ascertain their scientific characteristics. When the tourism resources are developed fully, it will ensure participatory justice, democratization, and empowerment with a sense of ownership to sustain management of the resources [24]. For local planning efforts to be effective, they have to reflect the wishes, traditions, and knowledge base of the local people [25]. In view of the research gap, much research work is needed to identify and name all local trees and butterflies at the sites scientifically.

Community-based ecotourism holds tremendous potential in providing local societies with economic benefits [2628]. Further, because ecotourism promotes conservation of local natural and cultural resources, benefit flows from ecotourism are sustainable. Tourists have made a lot of contributions to the social and economic development of the settlements visited. Proceeds from payment of access fees and accommodation generate revenue for local communities. With poverty rife at these tourist sites, the generosity of some tourists has also helped alleviate some of the challenges faced in these deprived communities endowed with the beauties of nature.

\section{Acknowledgments}

The authors acknowledge the Center for Remote Sensing and Geographic Information Services of the University of Ghana for making data available for this publication. Many thanks also go to Mr. Ansu Gyeabor and Mr. Emmanuel Tetteh for assisting in field data collection.

\section{References}

[1] D. Honeck, LDC Poverty Alleviation and the Doha Development Agenda: Is Tourism Being Neglected? World Trade Organization, 2008.

[2] UNCTAD, FDI in Tourism: The Development Dimension, UNCTAD Current Studies Bon FDI and Development No. 4, New York, NY, USA, 2007.

[3] S. Beeton, Community Development Through Tourism, Landlink Press, Victoria, Australia, 2006.

[4] M. McAlpin, "Conservation and community-based development through ecotourism in the temperate rainforest of southern Chile," Policy Sciences, vol. 41, no. 1, pp. 51-69, 2008.
[5] R. Scheyvens, Tourism for Development: Empowering Communities, Prentice Hall, Essex, UK, 2002.

[6] R. Naidoo, G. Stuart-Hill, L. C. Weaver, J. Tagg, A. Davis, and A. Davidson, "Effect of diversity of large wildlife species on financial benefits to local communities in northwest Namibia," Environmental and Resource Economics, vol. 48, no. 2, pp. 321-335, 2011.

[7] V. Havel, Reflections-What Is Participation, The World Bank Participation Sourcebook, The World Bank, 1996.

[8] J. MaCarthy, "Nature based tourism: case study of Gunung Leuser," Indonesia, 1999, http://www.istp.murdoch.edu.au/.

[9] World Travel and Tourism Environmental Research Centre (WTTERC), World Travel and Tourism Environment Review, World Travel and Tourism Environment Research Centre, Oxford, UK, 1993.

[10] C. M. Hall and S. J. Page, The Geography of Tourism and Recreation: Environment, Space and Place, Routledge, London, UK, 2006.

[11] V. C. Teye, "Commentary: tourism plans and Planning in Ghana," Tourism Geographies, vol. 1, no. 3, pp. 283-292, 1999.

[12] R. Ghosh and R. Kotey, Tourism Statistical Fact Sheet on Ghana, Institute of Statistical Social and Economic Research, University of Ghana, Accra, Ghana, 1973.

[13] G. Ayittey, The Tourism Multiplier Expenditure in Ghana, Department of Economics, University of Ghana, Tourist Control Board, Accra, Ghana, 1975.

[14] N. Erdogan and E. Baris, "Environmental protection programs and conservation practices of hotels in Ankara, Turkey," Tourism Management, vol. 28, no. 2, pp. 604-614, 2007.

[15] ISSER, State of the Ghanaian Economy in 2008, Institute of Statistical Social and Economic Research (ISSER), Legon, Ghana, 2008.

[16] J. R. Ayee, An Anatomy of Public Policy Implementation: The Case of Decentralisation Policies in Ghana (Avebury, Aldershot), Ashgate Publishing, Brookfield, Vt, USA, 1994.

[17] J. C. Murombedzi, "Devolution and stewardship in Zimbabwe's campfire program," Journal of International Development, vol. 11, pp. 287-293, 1999.

[18] J. I. Barnes, J. Macgregor, and L. C. Weaver, "Economic efficiency and incentives for change within Namibia's community wildlife use initiatives," World Development, vol. 30, no. 4, pp. 667-681, 2002.

[19] R. Pardini, "Effects of forest fragmentation on small mammals in an Atlantic Forest landscape," Biodiversity and Conservation, vol. 13, no. 13, pp. 2567-2586, 2004.

[20] L. Fahrig, "Relative effects of habitat loss and fragmentation on population extinction," Journal of Wildlife Management, vol. 61, no. 3, pp. 603-610, 1997.

[21] K. J. Feeley and J. W. Terborgh, "Direct versus indirect effects of habitat reduction on the loss of avian species from tropical forest fragments," Animal Conservation, vol. 11, no. 5, pp. 353-360, 2008.

[22] C. Kleinn, "New technologies and methodologies for national forest inventories," Unasylva, vol. 53, no. 210, pp. 10-15, 2002.

[23] S. Chiba, I. Okochi, T. Ohbayashi et al., "Effects of habitat history and extinction selectivity on species-richness patterns of an island land snail fauna," Journal of Biogeography, vol. 36, no. 10, pp. 1913-1922, 2009.

[24] S. Cole, "Information and empowerment: the keys to achieving sustainable tourism," Journal of Sustainable Tourism, vol. 14, no. 6, pp. 629-644, 2006. 
[25] T. William, New Geographies of the American West: Land Use and the Changing Patterns of Place, Island Press, Washington, DC, USA, 2007.

[26] V. Vincent and W. Thompson, "Assessing community support for eco-tourism development," Journal of Applied Research, vol. 41, pp. 153-160, 2002.

[27] S. Wunder, "Ecotourism and economic incentives-an empirical approach," Ecological Economics, vol. 32, no. 3, pp. 465-479, 2000.

[28] J. Whiteman, "Ecotourism promotes, protects environment," Forum for Applied Research and Public Policy, vol. 11, no. 4, pp. 96-101, 1996. 

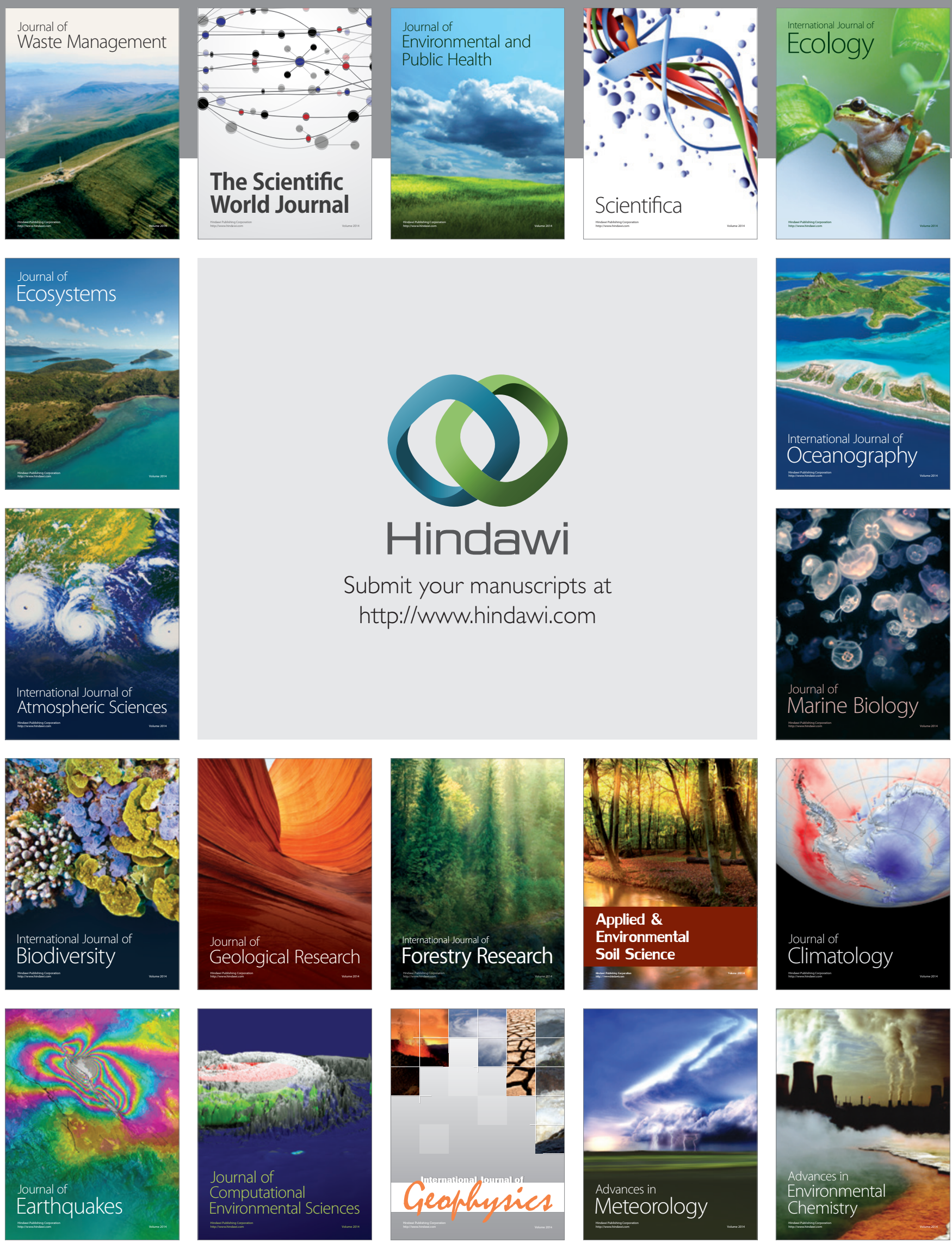